\title{
Presepsi Warga terhadap Covid 19
}

\author{
Ahmad Jarkasih \\ Madrasah Ibtidaiyah An-Nizhomiyah \\ acoselboghory@gmail.com
}

\begin{abstract}
The purpose of this study was to obtain information on people's perceptions of Covid 19. The study used qualitative methods to obtain information on people's perceptions of Covid 19. This study was limited to a sample size of 5 respondents who were in Cilodong Village, Cilodong District, Depok City. The results of the research are that. COVID-19 is a dangerous and contagious disease. The existence of COVID-19 in the world economic sector has decreased as well as in Indonesia, even many companies have gone out of business and laid off their employees because they cannot pay. Teaching and learning activities become obstructed. They always worry about traveling or working, therefore work is limited. From this, every citizen has positive expectations that every activity will return to normal.
\end{abstract}

Keywords: Citizen's Perception, COVID-19

\begin{abstract}
Abstrak
Tujuan dari penelitian ini adalah untuk mendapatkan informasi presepsi warga terhadap covid 19. Penelitian menggunakan metode kualitatif untuk mendapatkan informasi presepsi warga terhadap Covid 19. Penelitian ini terbatas pada ukuran sampel 5 responden yang berada di Kampung Cilodong Kecamatan Cilodong Kota Depok. Hasil dari penelitian di dapat bahwa. COVID-19 adalah penyakit yang berbahaya dan bisa menular. Adanya COVID-19 sektor perekonomian dunia menurun begitupun di Indonesia, bahkan banyak perusahaan yang gulung tikar dan merumahkan karyawannya karena tidak bisa menggaji. Kegiatan belajar mengajar menjadi terhambat. Mereka Selalu was-was dalam berpergian atau bekerja maka dari itu pekerjaan di batasi. Dari hal tersebut setiap warga memiliki harapan yang positif agar setiap kegiatan menjadi normal kembali.
\end{abstract}

Kata Kunci : Presepsi Warga, COVID- 19 PENDAHULUAN

Penyakit Virus Corona 2019 adalah kasus virus yang terjadi pertama kali di Wuhan Provinsi Hubei, sejak bulan desember 2019. Menurut penyelidikan oleh otoritas kesehatan di Negara Cina, corona virus baru ditemukan sebagai penyebab pandemi COVID-19. Gejala COVID-19 yang paling umum adalah demam, keletihan, batuk tidak berdahak, dan sesak nafas. Gejala lain yaitu hidung tersumbat, sakit kepala, konjungtivitis, sakit tenggorokan, diare, kehilangan kemampuan mengecap atau mencium, ruam kulit atau perubahan warna jari tangan atau kaki.

Dana Riksa Buana (2020) menyatakan bahwa pada awal tahun 2020 ini dunia dikejutkan dengan wabah virus corona (COVID-19) yang menginfeksi hampir seluruh negara di dunia dan masuk kedalam darurat global terkait virus, merupakan fenomena luar biasa yang terjadi di bumi pada abad ke 21, yang skalanya mungkin dapat disamakan dengan Perang Dunia II, karena event-event skala besar 
(pertandingan-pertandingan olahraga internasional contohnya, hampir seluruhnya ditunda bahkan dibatalkan, kemudian kondisi ini pernah terjadi hanya pada saat terjadi perang dunia saja, tidak pernah ada situasi lainnya yang dapat membatalkan acara-acara tersebut. Beberapa orang dapat terinfeksi namun hanya mengalami gejala sangat ringan atau tidak spesifik.

Dari teori di atas peneliti menyimpulkan bahwa Penyakit Virus Corona 2019 (COVID-19) adalah krisis kesehatan pertama dan terutama di dunia.

Untuk mengatasi dampak kesehatan/penularan dan dampak pada pendidikan dan sektor ekonomi virus Corona (COVID- Adapun menurut Kavita Ulumiyah (2020) mengatakan bahwa Virus Corona baru atau COVID19 saat ini telah menginfeksi orangorang di lebih dari 200 negara dengan jumlah kasus mencapai lebih dari dua juta dan mengakibatkan lebih dari 150 ribu orang meninggal dunia. Sedangkan menurut Taufik (2020) mengatakan bahwa COVID-19 telah menimbulkan economic shock, yang mempengaruhi ekonomi secara perorangan, rumah tangga, perusahaan mikro, kecil, menengah maupun besar, bahkan mempengaruhi ekonomi negara dengan skala cakupan dari lokal, nasional, dan bahkan global.

Untuk mengatasi dampak kesehatan atau penularan pada pendidikan dan dampak ekonomi virus Corona (COVID-19) maka perlu disikapi minimal dengan hal penting sebagai berikut. Pertama, pemerintah pusat dan daerah melakukan edukasi terhadap prilaku hidup sehat serta melakukan penyuluhan terhadap faktor penyebab munculnya virus Corona dan antisipasi terhadap penularannya. Kedua, kemerintah pusat dan daerah melalui dinas atau departemen terkait melakukan tindakan dalam upaya menenangkan hati dan pikiran masyarakat dengan cara menangkal pemberitaan-pemberitaan tidak benar sehubungan dengan adanya viru Corona (COVID-19) tersebut.

Untuk melakukan tindakan dalam upaya pencegahan terhadap virus ini, pemerintah harus serius untuk mengajak masyarakat menerapkan pola hidup sehat, karena masih banyak masyarakat yang belum bisa mempraktekkan hidup bersih, mencucui tangan, memakai masker, sosial distancing (berjaga jarak) dan menghindari kerumunan. 
Tujuan dari penelitian ini adalah untuk mendapatkan informasi mengenai presepsi warga masyarakat terhadap COVID-19 dan menggunakan metode kualitatif.

\section{KAJIAN TEORI}

\section{Presepsi (Perception)}

Kantowitz dalam Lufri (1998) mengatakan bahwa presepsi merupakan pengenalan dan interprestasi seseorang terhadap objek atau peristiwa yang kita pikirkan atau yang dirasakan. Menurut Solso dalam Lufri (1995) presepsi adalah deteksi atau interprestasi terhadap stimulus yang ditangkap oleh pengindraan. Sedangkan menurut Mayor polak dalam Lufri (1976) mengatakan presepsi adalah individu dituntut untuk memberikan penilaian terhadap suatu ojek, yang dapat bersifat positif atau negatif, senang atau tidak senang. Dengan adanya presepsi maka akan terbentuk sikap.

Dari teori di atas dapat menyimpulkan bahwa presepsi adalah stimulus terhadap individu dituntut untuk memberikan penilaian terhadap suatu ojek, yang dapat bersifat positif atau negatif, senang atau tidak senang. Dengan adanya presepsi maka akan terbentuk sikap.

\section{Warga atau Masyarakat}

Janu Murdiatmoko

(2006) mengatakan bahwa warga atau masyarakat adalah sekumpulan manusia, tentu akan mengalami perubahan karena ada dinamika sosial di dalamnya yang menandakan adanya kehidupan. Adapun menurut Lap Linthon dalam Mahyudin (2019) merupakan sekelompok mausia yang telah hidup dan bekerja bersama cukup lama, sehingga mereka dapat mengatur diri mereka dan menggap diri mereka sebagai suatu kesatuan sosial dengan batas-batas yang dirumuskan dengan jelas.

Soekanto dalam Mahyudin (2019) salah satu proses sosial yang bersifat tersendiri ialah dalam hal perubahanperubahan didalam struktur sosial. Sedangkan menurut Sugiyono (2012) populasi adalah wilayah generalisasi yang terdiri atas objek/subjek yang mempunyai kualitas dan karakteristik tertentu yang ditetapkan oleh peneliti untuk dipelajari dan kemudian ditarik kesimpulannya.

Dari teori diatas peneliti dapat menyimulkan dan mensintesakan bahwa warga atau masyarakat adalah sekumpulan manusia, tentu akan mengalami perubahan karena ada dinamika sosial di dalamnya yang 
menandakan adanya kehidupan dan salah satu proses sosial yang bersifat tersendiri ialah dalam hal perubahanperubahan didalam struktur sosial.

\section{Covid-19}

Dana Riksa Buana (2020) menyatakan pada awal tahun 2020 ini dunia dikejutkan dengan wabah virus corona (COVID-19) yang menginfeksi hampir seluruh negara di dunia dan masuk kedalam darurat global terkait virus, merupakan fenomena luar biasa yang terjadi di bumi pada abad ke 21, yang skalanya mungkin dapat disamakan dengan Perang Dunia II, karena eventevent skala besar (pertandinganpertandingan olahraga internasional contohnya, hampir seluruhnya ditunda bahkan dibatalkan, kemudian kondisi ini pernah terjadi hanya pada saat terjadi perang dunia saja, tidak pernah ada situasi lainnya yang dapat membatalkan acara-acara tersebut. Beberapa orang dapat terinfeksi namun hanya mengalami gejala sangat ringan atau tidak spesifik.

Adapun menurut Kavita Ulumiyah (2020) mengatakan bahwa Virus Corona baru atau COVID-19 saat ini telah menginfeksi orang-orang di lebih dari 200 negara dengan jumlah kasus mencapai lebih dari dua juta dan mengakibatkan lebih dari 150 ribu orang meninggal dunia. Sedangkan menurut Taufik (2020) mengatakan bahwa COVID-19 telah menimbulkan economic shock, yang mempengaruhi ekonomi secara perorangan, rumah tangga, perusahaan mikro, kecil, menengah maupun besar, bahkan mempengaruhi ekonomi negara dengan skala cakupan dari lokal, nasional, dan bahkan global.

Dari teori di atas peneliti menyimpulkan bahwa Penyakit Virus Corona 2019 (COVID-19) adalah krisis kesehatan pertama dan terutama di dunia. Pada awal tahun 2020 ini dunia dikejutkan dengan wabah virus corona (COVID-19) yang menginfeksi hampir seluruh negara di dunia. Virus Corona baru atau COVID-19 saat ini telah menginfeksi orang-orang di lebih dari 200 negara dengan jumlah kasus mencapai lebih dari dua juta dan mengakibatkan lebih dari 150 ribu orang meninggal dunia dan telah menimbulkan sekolah universitas dan pendidikan lain, kemudian economic shock, yang mempengaruhi ekonomi secara perorangan, rumah tangga, perusahaan mikro, kecil, menengah maupun besar, bahkan mempengaruhi ekonomi negara 
dengan skala cakupan dari lokal, nasional, dan bahkan global.

\section{METODOLOGI PENELITIAN}

Penelitian menggunakan metode studi kasus kualitatif yang digunakan untuk mendapatkan informasi Presepsi Warga Terhadap Covid 19. Penelitian ini terbatas pada ukuran sampel 5 responden, yang tinggal di sekitar wilayah Cilodong Kota Depok. Penelitian ini menggunakan penelitian kualitatif, dan sampel menggunakan purposive sampling. Pada penelitian ini, teknik purposive sampling adalah

Tabel. 1 Profil Responden

\begin{tabular}{|c|l|c|c|c|l|}
\hline No & \multicolumn{1}{|c|}{$\begin{array}{c}\text { Nama } \\
\text { Responden }\end{array}$} & JK & Usia & Pendidikan & \multicolumn{1}{|c|}{ Pekerjaan } \\
\hline 1. & SDR & L & 27 & S1 & $\begin{array}{l}\text { Staf Perpustakaan } \\
\text { Sekolah }\end{array}$ \\
\hline 2. & MS & P & 28 & S1 & Pegawai Swasta \\
\hline 3. & MNR & P & 27 & S1 & Pegawai Kantoran \\
\hline 4 & TN & L & 47 & S1 & Guru MI \\
\hline 5 & MNS & P & 26 & S1 & Security \\
\hline
\end{tabular}

Metode pengumpulan data terbatas pada ukuran sampel 5 primer, menggunakan observasi/wawancara semi terstruktur sedangkan data sekunder dikumpulkan dari data yang dipublikasikan seperti artikel, jurnal dan buku. Penelitian ini responden, yang tinggal di sekitar wilayah Cilodong Kota Depok. Bernadrd (2002) menyatakan tidak ada batasan jumlah responden untuk membuat sampel purposive, asalkan informasi 
yang diinginkan dapat diperoleh dan dihasilakan. Gay dan Diehl (1992) menyimpulkan bahwa semakin banyak sampel yang diambil maka akan semakin representatif dan hasilnya dapat digenelisir. Namun ukuran sampel yang diterima akan sangat bergantung pada jenis penelitiannya. Sugiyono (2007) mengatakan bahwa ada beberapa prinsip dalam penulisan angket sebagai teknik pengumpulan data, yaitu prinsip penulisan, pengukuran dan penampilan fisik. Sedangkan Wawancara menurut Nazir (1988) adalah proses memperoleh keterangan untuk tujuan penelitian dengan cara tanya jawab sambil bertatap muka antara si penanya atau pewawancara dengan si penjawab atau responden dengan menggunakan alat yang dinamakan interview guide (panduan wawancara). Walaupun wawancara adalah proses percakapan yang berbentuk tanya jawab dengan tatap muka, wawancara adalah suatu proses pengumpulan data untuk suatu penelitian.

Dari teori diatas peneliti dapat menyimpulkan dan mensintesiskan bahwa dalam batasan pengambilan observasi/wawancara jumlah responden tidak dibatasi asalkan informasi yang diinginkan dapat diperoleh dan dihasilakan, sedangkan dalam pengambilan data wawancara adalah proses percakapan yang berbentuk tanya jawab dengan tatap muka, dan suatu proses pengumpulan data untuk suatu penelitian.

Dalam

kegiatan wawancara/observasi dilakukan secara langsung dengan menggunakan protokol kesehatan. Saat wawancara, dilakukannya tanya jawab seputar presepsi tentang COVID- 19 peneliti meminta izin persetujuan kepada objek untuk bisa di wawancarai oleh peneliti. Pada saat dimulainnya wawancara peneliti menyiapkan beberapa pertanyaan. Sugiyono Menerangkan bahwa umumnya teknik pengambilan sampel ini diusahakan secara acak, teknik pengumpulan data menggunakan metode riset kualitatif, analisa data yang bersifat kualitatif ataupun statistik bertujuan untuk menguji hipotesis yang telah ditetapkan.

Dari teori di atas peneliti dapat menyimpulkan dan mensintesiskan bahwa pada teknik pengambilan data sampel diusahakan secara acak dan menggunakan metode kualitatif.

Adapun pertanyaan pertanyaan penelitian, yang diajukan teradap responden yaitu, bagaimana presepsi 
anda tentang COVID-19, pada saat COVID-19 kendala apa saja yang anda rasakan, bagaimana caranya agar anda dan keluarga menjaga kesehatan pada saat pandemi COVID-19.

\section{HASIL DAN PEMBAHASAN}

\section{Hasil Penelitian}

Tujuan dari penelitian ini adalah untuk mendapatkan informasi mengenai presepsi warga terhadap covid 19. Semua tanggapan peserta adalah kutipan asli, dan mereka telah dikutif sebagaimana dinyatakan oleh para responden.

Penelitian menggunakan metode studi kasus kualitatif yang digunakan untuk mendapatkan informasi Presepsi Warga Terhadap Covid 19. Penelitian ini terbatas pada ukuran sampel 5 responden, yang tinggal di sekitar wilayah Cilodong Kota Depok. Penelitian ini menggunakan penelitian kualitatif, dan sampel menggunakan purposive sampling. Pada penelitian ini, teknik purposive sampling adalah metode yang digunakan untuk mencapai tujuan penelitian tertentu.

Wawancara semi terstuktur dilakukan dan daftar pertanyaan disusun untuk wawancara dikembangkan berdasarkan literatur terkait. Responden penelitian ini adalah warga yang ada disekitar wilayah Cilodong Kota Depok. Verifikasi merupakan kegiatan yang dilakukan selama penelitian berlangsung, pengambilan data diperoleh dari observsi dan wawancara di verifikasi dari sumber data berupa triangulasi sumber yang digunakan dalam penelitian kualitatif ini. Analisis dan interprestasi data adalah bagian paling kritis dari penelitian kualitatif. Untuk menggali dan mendapatkan informasi tentang presepsi warga terhadap covid 19 dibuat beberapa pertanyaan penelitian yangh diajukan kepada responden.

\section{Pembahasan}

Adanya COVID-19 mejadi dampak yang sangat besar terhadap kegiatan masyarakat. Beberapa dampak diantaranya, tidak bisa bekerja seperti biasa, banyak batasan-batasan satu sama lainnya. Penghasilan dalam pekerjaan menurun. Kurangnya pemasukan, banyak pekerja dirumahkan atau di PHK. Pada saat pandemi COVID-19 sebagian masyarakat melakukan pekerjaannya dirumah (work from home), karena anjuran dari pemerintah setempat dalam keadaan pandemi ini, maka dari itu penghasilan mereka menurun. 
"Minimnya penghasilan, tidak bisa bekerja seperti biasa" (kutipan wawancara dengan SDR)

"Selalu was-was dalam bekerja, banyak karyawan yang dirumahkan" (kutipan wawancara dengan MS)

Tempat rekreasi banyak yang di tutup, silaturahmi kepada saudara mulai dibatasi, ketika berpergian keluar rumah harus menggunakan masker, mencuci tangan dengan sabun. Banyak keluarga yang mengeluh dengan kondisi ekonomi di keluarganya, terutama dengan pembelian paket kuota internet untuk belajar anaknya dengan biaya yang cukup besar.

"Kegiatan masyarakat dibatasi, kondisi ekonomi dalam keluarga tidak stabil" (kutipan wawancara dengan $M N R)$

Banyak diantara warga untuk berpergian ketempat keramaian mereka merasa was-was dengan adanya pandemi saat ini, sebagian besar pegawai bekerja di rumah diberikan jadwal secara bergiliran, pelayanan masyarakat dibatasi di kantor-kantor pemerintahan maupun swasta, ada yang bekerja sebagai guru honorer dan PNS mereka mengeluh, karena mereka harus memberikan materi secara online, sedangkan mereka juga harus menghadapi kendala dengan teknologi yang belum mereka kuasai, tetapi mereka memikirkan siswanya dalam mengejar materi pembelajaran yang diajarkan agar bisa tercapai dengan maksimal, warga pun belum bisa melaksanakan ibadah solat berjamaah di masjid karena larangan oleh pemerintah untuk menjaga penularan COVID-19 . Maka dari itu warga di anjurkan diam di rumah, kecuali ada kepentingan yang sangat penting, mereka pergi keluar dengan keadaan mengikuti protokol kesehatan.

$$
\text { "Pelayanan }
$$

dikantor pemerintahan dan swasta dibatasi, kegiatan belajar menggunakan sistem online” (kutipan wawancara dengan $T N)$

Untuk bisa menjaga diri dan keluarga dari penularan Covid 19 maka sudah seharusnya kita membiasakan pola hidup sehat, di indonesia terutama di tempat yang diteliti, yaitu daerah cilodong sebagian besar warganya mau tidak mau merubah pola hidup yang dibilang baru, yaitu membiasakan memakai masker, mencuci tangan dengan sabun, menjauhi tempat kerumunan, karena di sekitar mereka sudah banyak yang terpapar COVID-19 
dan merekapun tidak bisa hidup tenang sebelum pandemi COVID-19 berakhir.

"Membiasakan pola hidup sehat agar terhindar dari penularan covid 19", (kutipan wawancara dengan MNS)

Bastaman

mengemukakan bahwa makna hidup adalah hal-hal yang dipandang penting, dirasakan berharga dan diyakini sebagai sesuatu yang benar sarta dapat dijadikan tujuan hidupnya. Makna hidup bila berhasil ditemukan dan dipenuhi akan menyebabkan kehidupan ini berarti dan biasanya individu yang menemukan dan mengembangkannya akan terhindar dari keputus asaan. Menurut Zhao (2003) tinjauan literatur saat ini telah menemukan bahwa ada banyak penelitian tentang implementasi teknologi dalam pendidikan online berkaitan dengan penghematan biaya dan efisiensi, bahwa peningkatan kualitas dan efektivitas pendidikan online memerlukan kerangka kerja yang harus diterapkan di sekolah .Kerangka yang diusulkan memberikan panduan praktis kepada para pemangku kepentingan dalam penilaian kualitas pengajaran dan pembelajaran online. Chakraborty (2014) mengungkapkan beberapa faktor yang dapat menciptakan pengalaman belajar yang menarik bagi pembelajar online. Faktor utama adalah sebagai berikut: menciptakan dan memelihara lingkungan belajar yang positif; membangun komunitas belajar; memberikan umpan balik yang konsisten secara tepat waktu; dan menggunakan teknologi yang tepat untuk mengirimkan konten yang tepat. Widyati R (2002) higiene adalah suatu pemecahan penyakit yang menitik beratkan pada usaha kesehatan perorangan atau manusia beserta lingkungan tempat orang tersebut berada, dan sanitasi suatu usaha pencegahan penyakit yang menitik beratkan kegiatan kepada uapaya kesehatan lingkungan hidup manusia. Triatmoko (2009) mengemukakan pendapatnya bahwa pekerjaan aktivitas yang dilakukan oleh manusia baik itu secara individu maupun secara berkelompok, baik secara terbuka maupun tertutup kemudian dari kegiatan tersebut bisa mengahsilkan suatu produk baik barang atau jasa sehingga dapat memperoleh uang dan dijadikan sebagai mata pencaharian. Pekerjaan juga bisa didefenisikan sebagai suatu aktivitas yang wajib dilakukan oleh setiap orang untuk memenuhi segala kebutuhannya dan demi kelangsungan hidupnya. Sedangkan menurut Luthan (2012) kepuasan kerja adalah hasil dari persepsi 
karyawan mengenai seberapa baik pekerjaan mereka memberikan hal yang dinilai penting. Menurut Tiffin Kinanti (2012) berpendapat bahwa kepuasan kerja berhubungan erat dengan sikap dari karyawan terhadap pekerjaannya, sendiri, situasi kerja, kerjasama antara pimpinan dengan sesama karyawan.

Dari beberapa teori di atas peneliti dapat menyimpulkan dan mensintesakan bahwa makna hidup adalah hal-hal yang dipandang penting, dirasakan berharga dan diyakini sebagai sesuatu yang benar sarta dapat dijadikan tujuan hidupnya. Makna hidup bila berhasil ditemukan dan dipenuhi akan menyebabkan kehidupan ini berarti dan biasanya individu yang menemukan dan mengembangkannya akan terhindar dari keputus asaan

\section{KESIMPULAN}

Hasil penelitian menunjukan secara umum presepsi warga terhadap COVID-19 adalah penyakit yang menular dan berbahaya, di berbagai negara, di Indonesia maupun di daerah terpencil sekalipun salah satunya di wilayah Cilodong sudah ada yang terpapar virus COVID-19. Indonesia atau negara lainnya memutuskan untuk menutup sekolah dan perguruan tinggi.
Sistem belajar mengajar menggunakan media daring atau online, siswa belajar di rumah dan diberikan materi pembelajaran oleh gurunya lewat media sosial. Dari segi pembelajaran daring, banyak guru yang mengalami kendala dalam memberikan materi bahan ajar, karena berbenturan dengan teknologi saat ini sedangkan mereka belum menguasai sepenuhnya, sebaliknnya orang tua murid yang mengarahkan anaknnya belajar dirumah juga mempunyai kendala yang sama, ditambah dengan keluhan pembelian paket kuota internet.

Pandemi

COVID-19, mengakibatkan sektor perekonomian, perpajakan, pemerintahan di dunia, terutama di Indonesia menjadi menurun, bahkan banyak perusahaan yang gulung tikar karena tidak bisa lagi membayar gaji karyawannya, dari situ banyak pekerja dirumahkan atau di PHK.

Kegiatan aktivitas warga menjadi terhambat dan dibatasi. Berpergian keluar rumah, mereka wajib mematuhi peraturan pemerintah setempat dan wajib menggunakan protokol kesehatan seperti memakai masker dan mencuci tangan, menghindari dari tempat keramaian. Dari hal tersebut setiap warga memiliki harapan yang positif 
agar pandemic ini cepat berlalu dan semua aktivitas menjadi normal kembali

\section{DAFTAR PUSTAKA}

Agus Purwanto. Studi Eksploratif Dampak Pandemi COVID-19 Terhadap Proses

Bastaman, 1996. Pengertian dan Teori Kepuasan Kerja Menurut Para Ahli Retrieved Agustus, 182020 from

https://www.academia.edu/9618 759/PENGERTIAN_KEHIDUP AN_MENURUT_PARA_AHLI

Gay dan Diehl, 1992. Ukuran Sampel Penelitian yang Memenuhi Syarat Menurut Para Ahli Retrieved Agustus, $19 \quad 2020$ from https://statmat.id/ukuran-sampelpenelitian

Iwan Setiawan. Penyakit Virus Corona 2019 (COVID-19 ) 2020, Jakarta: Universitas, Indonesia

Janu Murdiyatmoko. (2006).Sosiologi Memahani dan Mengkaji Masyarakat Kelas XII. Yogyakarta: Grafindo Media Pratama

Kavita Ulumiyah. Dampak Covid-19 Terhadap Sektor Ekonomi Dan Sektor Pajak Indonesia. 2020, Surabaya: Fakultas Ekonomi Universitas PGRI Adi Buana Surabaya

Lurfi. (2020).Metodologi

Pembelajaran:Strategi,

Pendekatan, Model, Metode Pembelajaran. Malang: CV IRDH

Luthan. (2012). Hubungan Indrustial dan Kompensasi. Dalam Luis
Marsinah. Teori Politik.Jogjakarta: CV BUDI UTAMA.

Nazir, 1998. Teknik Pengumpulan Data Wawancara, Angket dan Observasi Retrieved Agustus, 18 2020 from https://karyatulisku.com/teknikpengumpulan-data-wawancara/

Pembelajaran Online di Sekolah Dasar, 2020, Jakarta: Universitas Pelita Harapan, Indonesia

Raka Lestari, 2020. 4 Kelompok yang Rentan Terjangkit Virus Korona Retrieved Agustus, 182020 from https://www.msn.com/idid/kesehatan/medis/4-kelompokyang-rentan-terjangkit-viruskorona/ar-BB11r0Iu

Sugiyono. (2012).Metode Penelitian. Dalam Mamik. Metode Penelitian Kesehatan.Jawa Tengah: ZIFATAMA Publisher.

Sujarweni. (2008).Metodologi Penelitian Kesehatan dan Pendidikan. Dalam Syamsunie.Jogjakarta: Penebar Media Pustaka.

Tiffin Kinanti, 2012. Pengertian Kehidupan Menurut Para Ahli Retrieved Agustus, 182020 from https://www.academia.edu/3900 1249/Pengertian_dan_Teori_Ke puasan_KerjaMenurut_Para_Ahl i_www_universitaspsikologi_co $\underline{\mathrm{m}}$

Triatmoko. (2012).Sukses Mendapatkan Pekerjaan Impian.Jakarta: PT Tangga Pustaka.

Wayan Pasek Agus Mahardika, 2020. Dampak Corona Covid 19 terhadap Perekonomian di 
12 | Transformasi Manageria, Vol. 1, No. 1, Juni 2021

Indonesia Retrieved Agustus, 18 2020 from https://www.kompasiana.com/pas ekagusmahardika/5e7f5456d541d f27bc2c0b32/dampak-coronaCOVID-19 -terhadapperekonomian-di-indonesia.

Widyati R. (2002). Pengantar Kesehatan Lingkungan. Dalam Muhammad Ikhtiar.Jakarta: PT Tangga Pustaka. 